Provision of information and educational needs of foreign students as an integral part of the activity of the scientific and technical library of the National aviation university 
УДК 025.5:027.7- 0.57.875-054.6 (045)

DOI: 10.31470/2518-7600-2019-8-224-248

PROVISION OF INFORMATION AND EDUCATIONAL NEEDS OF FOREIGN STUDENTS AS AN INTEGRAL PART OF THE ACTIVITY OF THE SCIENTIFIC AND TECHNICAL LIBRARY OF THE NATIONAL AVIATION UNIVERSITY

\section{ЗАБЕЗПЕЧЕННЯ ІНФОРМАЦІЙНО-ОСВІТНІХ ПОТРЕБ СТУДЕНТІВ-ІНОЗЕМЦІВ ЯК НЕВІД'СМНА СКЛАДОВА ДІЯЛЬНОСТІ НАУКОВО-ТЕХНІЧНОЇ БІБЛІОТЕКИ НАЦІОНАЛЬНОГО АВІАЦІЙНОГО УНІВЕРСИТЕТУ}

\section{ОБЕСПЕЧЕНИЕ ИНФОРМАЦИОННО- ОБРАЗОВАТЕЛЬНЫХ НУЖД} СТУДЕНТОВ-ИНОСТРАНЦЕВ КАК НЕОТЬЕМЛЕМАЯ СОСТАВЛЯЮЩАЯ ДЕЯТЕЛЬНОСТИ НАУЧНОТЕХНИЧЕСКОЙ БИБЛИОТЕКИ НАЦИОНАЛЬНОГО АВИАЦИОННОГО УНИВЕРСИТЕТА

Тетяна Курченко, кандидат історичних наук, доцент, доцент кафедри історії та документознавства, t.kurchenko@ukr.net, https://orcid.org/0000-00032704-6482 https://www.researchgate.net/pro file/

Національний авіаційний університет пр-т Космонавта Комарова, 1, ауд. 8-603, м. Київ, Україна 03058
Tetiana Kurchenko, $\mathrm{Ph} . \mathrm{D}$ in Historical Sciences, Associate Professor, Associate Professor of Department of History and scientific discipline of Documentation t.kurchenko@ukr.net, https://orcid.org/0000-00032704-6482

https://www.researchgate.net/pr ofile/

National Aviation University Prosp. Kosmonavta Komarova, 1, aud. 8-603, Kyiv, Ukraine 03058 


\section{ABSTRACT}

The article summarizes practical experience of providing information and educational needs of foreign students in the Scientific and Technical Library of the National Aviation University. The analysis of theoretical principles and state-of-the-art practical experience of organizing work with foreign students in higher educational establishments of Ukraine has been carried out, the peculiarities of this category of students have been revealed in relation to providing information needs in the learning process, simplifying their adaptation to the educational, informational and everyday environment of the host country.

The article states that the National Aviation University is one of the leading educational institutions providing training for foreign students. It has been found that the Scientific and Technical Library of the National Aviation University provides information and services to foreign students on a general basis and does not have a separate structural unit within it to work only with this group of students. Still, sufficient conditions for intellectual and physical access to information resources have been established for foreign students through the library website and in its computer classrooms. The article also presents the issues related to the direct service of foreign students in library units and professional readiness of the library staff to communicate with specific nature.

It has been found that the Scientific and Technical Library of the National Aviation University, over the decades of working with foreign students, has gained interesting and useful experience in organizing work with this category of readers and providing their information and educational needs. The necessity to generalize and share such experience, as well as to improve the provision of information needs offoreign students in the Scientific and Technical Library of the National Aviation University.

Key words: information, information services, information and educational needs, foreign students, library, Scientific and Technical Library of the National Aviation University.

Постановка проблеми. Як відомо, сучасні теорії соціального розвитку людини, на одне 3 перших місць висувають освіту. Основною тенденцією розвитку сучасної 
освіти, стає її безперервність що передбачає виховання молодої людини як особистості, орієнтованої на навчально-пізнавальну діяльність впродовж усього життя. Внаслідок утвердження в суспільстві таких поглядів, а також зростаючої мобільності молоді як читачів, істотно змінюються функції багатьох бібліотек, особливо університетських. Вони безпосередньо залучаються до виконання завдань навчального процесу, забезпечуючи його інформаційну підтримку, надаючи різноманітні інформаційно-освітні послуги.

Вивчення і задоволення інформаційних потреб студентів $\epsilon$ сьогодні актуальними завданнями для бібліотекознавства, документознавства, інформатики. У теоретичному бібліотекознавстві та практичній діяльності бібліотек вивчення інформаційних потреб читачів $є$ однією 3 умов створення ефективних систем інформаційного обслуговування, бібліографічного забезпечення та надання якісних інформаційно-освітніх послуг. Відомо, що інформаційна потреба завжди пов'язана 3 конкретною проблемою і залежить як від структури цієї проблеми, так і від багатофакторної характеристики споживача інформації, а також від мети використання інформації. Якщо ж споживач інформації має певні відмінні споживацькі характеристика, то їх вивчення, як і вивчення особливостей його інформаційних запитів, мають особливу вагу для бібліотечної установи. В повній мірі це твердження стосується студентів-іноземців, що отримують освітні послуги у закладах вищої освіти України.

Навчання іноземних студентів в Україні $є$ одним із напрямів розвитку сучасної системи національної освіти, оскільки сприяє підвищенню іміджу української вищої школи на світовому рівні, а також $\epsilon$ додатковим джерелом фінансування економіки держави.

Практика отримання освіти іноземними громадянами була започаткована ще в часи СРСР, щоправда в 1960-80-х роках більшість іноземних студентів навчалися лише в елітних закладах вищої освіти країни. Сьогодні освітній простір для більшості студентів-іноземців став значно ширшим. Це стало наслідком кардинальних змін, що відбулися у вітчизняному суспільстві з початку 90-х років, коли Україна здобула 
незалежність. Здобуття Україною незалежності безумовно вплинуло на розширення іiі контактів $з$ іншими країнами. Як наслідок, заклади вищої освіти України стали приймати іноземців на навчання як за міждержавними угодами, так і на комерційній основі, що $є$ свідченням зростання ваги українського диплому про вищу освіту в світовому освітньому просторі та у роботодавців.

Враховуючи позитивний досвід навчання іноземних студентів у вітчизняних закладах вищої освіти, слід зазначити, що важливими складовими механізму забезпечення привабливості вітчизняної вищої освіти для іноземців $\epsilon$ доступність освіти та її якість, де остання визначається такими критеріями, як кадровий потенціал, матеріально-технічний, сучасний стан методичного та інформаційного забезпечення навчального процесу.

Тому все, що пов'язане з навчанням студентів-іноземців і забезпеченням їх інформаційно-освітніх потреб бібліотеками закладів вищої освіти є важливим і актуальним.

Одним з провідних державних ЗВО України, який має великий досвід підготовки іноземних студентів, $\epsilon$ Національний авіаційний університет. Національний авіаційний університет (далі - НАУ) є провідним авіаційним закладом вищої освіти України, що за свою історію підготував десятки тисяч спеціалістів для більш ніж 140 країн світу і продовжує їх підготовку за перспективними спеціальностями сьогодні. На вересень 2019 р. в його стінах навчалось 918 іноземних студентів. НАУ займає 5 місце серед київських вишів, де проходять навчання студенти-іноземці і 25 місце в цілому по країні (Офіційний веб-сайт Інституту міжнародного співробітництва і освіти HAУ, URL: https://imco.nau.edu.ua/).

Без сумніву, досвід набутий в процесі задоволення інформаційно-освітніх потреб іноземних студентів в одній із найбільших науково-технічних бібліотек університетів, якою являється НТБ Національного авіаційного університету (далі НТБ НАУ), є цікавим та корисним.

Аналіз досліджень і публікацій. Актуальність проблеми забезпечення інформаційно-освітніх потреб іноземних студентів бібліотеками закладів вищої освіти обумовлює 
інтерес до неї науковців. Над загальною проблемою інформаційного обслуговування читачів в сучасних бібліотечних закладах плідно працюють науковці Ж. Бабенко (Бабенко, 2001); С. Борик (Борик, 2013); Т. Коваль (Коваль, 2007, 2012), Г. Ковальчук (Ковальчук, 2013), Н. Коржик (Коржик, 2007), Д. Нікола (Нікола, 2009), І. Нілова (Нілова, 2000), Т. Павленко (Павленко, 2012); Т. Ткаченко (Ткаченко, 2008), О. Шилюк (Шилюк, 2008) та ін. Різним аспектам організації навчання іноземних студентів та їх інформаційного забезпечення присвятили свої публікації О. Бакало (Бакало, 2015), Н. Мельник (Мельник, 2003), О.Тіщенко (Тіщенко 2013, 2014). Починаючи 3 кінця 90 років XX століття і дотепер 3'явилось ряд дисертаційних досліджень, що вивчають проблеми навчання студентів-іноземців та особливості організації роботи з ними в закладах вищої освіти України та університетських бібліотеках, зокрема, це дисертації О. Бакало (Бакало, 2017), Т. Довгодько (Довгодько, 2014), Л. Рибаченко (Рибаченко,2001) О. Татьянченко (Татьянченко,1997), Н. Терещ енко (Терещенко, 2005).

Особливості роботи із контингентом іноземних студентів безпосередньо в НАУ висвітлює в своїх публікаціях О. Бакало (Бакало, 2015), I. Зарубінська (Зарубінська, 2013), Т. Курченко і Ж. Паскал (Курченко \& Паскал, 2017). Разом з тим, проблема забезпечення інформаційних потреб іноземних студентів в НТБ НАУ ще ніколи не була предметом дослідження.

Мета статті - узагальнення досвіду забезпечення інформаційно-освітніх потреб студентів-іноземців в Науковотехнічній бібліотеці Національного авіаційного університету.

Виклад основного матеріалу. Головна місія сучасної бібліотеки закладу вищої освіти (далі - 3ВО) - підтримка навчання і наукових досліджень у виші шляхом створення необхідних умов для доступу до інформації та бібліотечних послуг. Поширення новітніх технічних засобів обробки інформації та сучасних форм доступу до неї на основі комп'ютерних технологій, формують нову концепцію розвитку бібліотеки, в якій пріоритет віддається інформаційній функції. 
Сьогодні саме бібліотеці належить особлива унікальна роль у формуванні інформаційного середовища. Треба визнати, що це досить відповідальний виклик для бібліотек, оскільки відбуваються суттєві зміни як у складі інформаційних ресурсів (електронні каталоги, електронні документи), так і в способах користування ними (віддалений доступ до баз даних, інтерактивний пошук інформації, електронна доставка документів та ін.). Для бібліотеки ЗВО новітні інформаційні ресурси мають впроваджуватися досить оперативно, адже контингент читачів бібліотеки - це молодь, яка однією 3 перших освоює та застосовує у своїй діяльності все нове та прогресивне.

Бібліотека 3ВО має постійно працювати над створенням інформаційного ресурсного середовища для підтримки навчального та наукового процесів, інноваційної діяльності вишу, надаючи студентам та викладачам різноманітні бібліотечно-інформаційні сервіси та послуги, дотримуючись принципів їх відкритості та доступності. На думку фахівців, до основних складових процесу інформаційного обслуговування користувачів у бібліотеці ЗВО слід віднести наступні: вивчення інформаційних запитів; інформаційно-ресурсне забезпечення; зміна ролі бібліотекаря в новому інформаційно-освітньому середовищі; просування інформаційних послуг в середовище закладу вищої освіти.

Серед вказаних складових процесу інформаційного обслуговування читачів важливу роль займає вивчення їх інформаційних запитів, адже впровадження сучасних інновацій відбувається виключно для того, щоб відповідати потребам і очікуванням зацікавлених сторін. Зацікавлена сторона, у даному контексті - це студенти та викладачі 3ВО, які оцінюють результативність і ефективність організованого в бібліотеці процесу інформаційного обслуговування: повноту і якість задоволення інформаційних запитів, різноманітність сервісів і послуг, оперативність їх надання. Плануючи загальну концепцію розвитку бібліотеки та розвиток бібліотечних сервісів слід враховувати особливості інформаційних запитів та очікувань різних категорій читачів. 
Сьогодні в ЗВО України навчається значна кількість студентів-іноземців. Наявність у закладі вищої освіти іноземних студентів $є$ своєрідним індикатором якості підготовки у ньому фахівців, його престижу та іміджу. Це особлива і доволі складна категорія студентів. Світовий та вітчизняний досвід свідчить про те, що передумовою успішного навчання іноземних студентів у чужій для них країні $\epsilon$ створення для них оптимальних умов для максимально безболісної адаптації - пристосування до нових, незвичних умов життя та навчання в Україні. Практичний досвід роботи 3 іноземними студентами показує, що в процесі їх адаптації можна виокремити декілька складових: адаптація до нових кліматогеографічних умов країни перебування; соціокультурна та побутова адаптація; мовна адаптація; академічна адаптація (Бакало, 2015). Всі ці особливості слід враховувати закладам вищої освіти, що надають освітні послуги іноземним громадянам.

Національний авіаційний університет є одним із закладів вищої освіти, що готує іноземних студентів по багатьом спеціальностям, його керівництво добре усвідомлює свої завдання і рівень відповідальності, який лягає на всі його структурні підрозділи, в тому числі і на бібліотеку. В складі НАУ діє Інститут міжнародного співробітництва і освіти, метою якого є реалізація заходів, передбачених Стратегією інтернаціоналізації співробітництва в галузі освіти Національного авіаційного університету. В університеті є повне розуміння того, що його привабливість та престижність для іноземних студентів не $\epsilon$ чимось назавжди сталим та беззаперечним і що треба постійно удосконалювати зміст навчання, запроваджувати сучасні форми та методи організації навчального процесу та підвищувати якість підготовки фахівців в цілому, у тому числі, шляхом все більшої індивідуалізації їх навчання. Зокрема, в НАУ іноземці навчаються в академічних групах із малою кількістю студентів; для них організовуються додаткові навчальні заняття та консультації; наставниками їх академічних груп призначаються найбільш досвідчені викладачі; у гуртожитках створюються більш комфортні умови тощо. Шлях в НАУ для студента- 
іноземця починається 3 підготовчого відділення, яке було відкрите в 1977 році, згідно наказу Міністра цивільної авіації СРСР. Далі іноземні студенти продовжують освіту у профільних інститутах та факультетах денної, заочної та дистанційної форм навчання. Іноземці навчаються також в аспірантурі та докторантурі університету. Піклуючись про майбутнє своїх вихованців, Національний авіаційний університет, з метою підвищення їх конкурентоздатності на вітчизняному та світовому ринку праці, з 1999 року успішно реалізує у навчальному процесі так званий «англомовний проект», в рамках якого підготовка фахівців за 20 найбільш популярними спеціальностями здійснюється виключно англійською мовою. У англомовних академічних групах навчаються не тільки громадяни України, але й громадяни країн близького та далекого зарубіжжя. Випускники «англомовного проекту» отримують диплом фахівця державного зразка та сертифікат, що підтверджує професійний рівень володіння англійською мовою (Зарубінська, 2013).

Усі іноземні студенти користуються Науково-технічною бібліотекою НАУ 3 моменту початку навчання. Науковотехнічна бібліотека є максимально наближеною до навчальних корпусів і студентських гуртожитків, отже є для студентівіноземців бібліотекою першого вибору і на неї лягає основне інформаційне забезпечення освітнього процесу. Врахуємо, що забезпечення інформаційно-освітніх запитів іноземних студентів має дві складові: інформаційне забезпечення та інформаційне обслуговування. Обидва напрями можуть реалізовуватись університетською бібліотекою двома шляхами: на загальних засадах, тобто студенти-іноземці обслуговуються на рівні $з$ іншими, та шляхом виокремлення в бібліотеці окремих каталогів, окремого місця обслуговування тощо. Науково - технічна бібліотека НАУ здійснює інформаційне забезпечення та обслуговування іноземних студентів на загальних засадах i не має у своєму складі окремого структурного підрозділу для роботи лише 3 даним студентським контингентом. Лише на першому році навчання студенти мають можливість користуватись літературою 3 окремого навчально-методичного кабінету, що існує при 
підготовчому відділенні й є укомплектованим спеціальною літературою, відповідно до навчальних занять і специфіки контингенту студентів-іноземців. Щоправда це не виключає можливості отримати інформаційне обслуговування в НТБ НАУ на загальних засадах.

Для іноземних студентів в НТБ НАУ створені достатні умови для інтелектуального та фізичного доступу до інформаційних ресурсів через веб-сайт бібліотеки, в іï комп'ютерних класах, в читальних залах та через абонемент. Науково-пошуковий апарат бібліотеки, розміщений на вебсайті НТБ, має крім основної української мови переклад на англійську та російську. Всі сервіси бібліотеки також доступні на англійській мові. Через веб-сайт НТБ НАУ можливий вихід на сайти 7 найвідоміших світових бібліотек, в тому числі Бібліотеки Конгресу США, Британської бібліотеки, Національної бібліотеки Німеччини та 10 найбільших бібліотечних закладів України. Бібліотечний підрозділ НАУ має у своєму складі окремий фонд літератури на іноземних мовах: англійській, німецькій, іспанській, польській, чеській, литовській тощо. Фонд має окремий каталог, виділений як на сайті бібліотеки, так і в «живих» каталогах. Здебільшого це література технічного спрямування, щоправда вона $є$ дещо застарілою і потребує оновлення. Отримати літературу на іноземній мові можна на абонементі та познайомитись 3 iii електронною версією в комп'ютерних класах, в читальних залах. Через ком’ютерний клас іноземні студенти мають також доступ до англомовних версій 10 наукових періодичних видань, що виходять в НАУ. Через сайт студенти мають також віддалений доступ до университетского репозитарію, де розміщені повнотекстові версії праць науковців НАУ, в тому числі i на іноземних мовах. Навчально-методичною літературою на англійській мові в повному обсязі забезпечуються студенти-іноземці, що навчаються на англомовному проекті. Якщо студенти - іноземці навчаються в змішаних групах, то вони забезпечуються або підручниками на англійській мові, або спеціальними методичними посібниками на українській або російських мовах, де виклад матеріалу орієнтований та їх рівень знання мови, з вживанням спрощеної лексики. 
Структурно-функціональна

модель

системи інформаційного обслуговування іноземних студентів, що практикується в НТБ НАУ, включає два взаємозалежних напрями діяльності: організаційний - систему інформаційного забезпечення (наявність інформаційно-ресурсного забезпечення бібліотекою інформаційних потреб іноземних студентів) та виконавчий - систему інформаційного обслуговування (можливість доступу до інформаційних ресурсів). Така модель створює базу для формування відповідної системи бібліотечного обслуговування, яка задовольняє потреби іноземних студентів в освітньоінформаційних послугах. Вона сприяє постійному зростанню освітнього i наукового потенціалу, розвитку іноземних студентів як майбутніх фахівців та повне задоволення інформаційних потреб іноземців, що виникають в процесі освіти. На думку I. Зарубінської, яка довгий час очолювала напрямок міжнародної діяльності НАУ, зазначена система дозволяє працівникам НТБ НАУ максимально врахувати інформаційні потреби та індивідуальні особливості студентів, що поліпшують освітньо-інформаційне забезпечення іноземців та ефективність їхнього освітнього процесу (Зарубінська, 2013).

Сьогодні вищеописана система знаходить своє відображення в роботі різноманітних відділів НТБ НАУ:

- відділ інформаційно-аналітичної та довідковобібліографічної роботи (відділ бібліографії). Працівники даного відділу обслуговують іноземних студентів шляхом надання допомоги у виявленні публікацій за певний період часу 3 тематики; виявлення публікації 3 тематики наукових досліджень; пошуку необхідних іноземним студентам матеріалів для виконання самостійних робіт; ознайомлення 3 публікаціями викладачів та науковців НАУ; надання довідки про місце зберігання потрібних матеріалів, уточнення бібліографічних даних, фактографічних відомостей; відповіді на питання у віртуальній довідці, створеній для науковців НАУ;

- відділ наукової обробки документів та організації каталогів. Працівники відділу надають іноземним студентам допомогу 3 наступних питань: консультація 3 пошуку 
інформації у системі каталогів; добір джерел за темами; визначення систематичного шифру видання за таблицями класифікації ББК;

- відділ навчальної літератури для молодших курсів. В даному відділі іноземні студенти молодших курсів (I та II курси) мають можливість оформити абонемент, укомплектований літературою технічного та гуманітарного профілів у відповідності з навчальними планами першого i другого курсів усіх інститутів та факультетів, яка може видаватися в автоматизованому режимі, в тому числі на основі попередніх замовлень через Інтернет;

- відділ навчальної літератури для старших курсів (III-VI курси). Повноваження цього відділу поширюються не лише на студентів денної форми навчання, але і на «заочників», слухачів Інституту післядипломної освіти, аспірантів і докторантів, представників постійного викладацького складу університету, а також слухачів факультету по роботі 3 іноземними студентами;

- відділ навчальної літератури у складі факультету міжнародних відносин. Даний відділ НТБ НАУ є структурним підрозділом, який розташовано на території факультету міжнародних відносин НАУ. Абонементом та читальним залом відділу мають можливість користуватись всі студенти i викладачі означеного факультету, а також представники інших навчальних структур. На території відділу розміщено Інформаційний центр Свропейського союзу;

- читальний зал технічної літератури. Зал пристосований до автоматизованого обслуговування читачів, тому не викликає додаткових проблем при обслуговуванні іноземних студентів;

- міжбібліотечний абонемент (МБА). В рамках обслуговування іноземних студентів МБА, вони мають можливість отримати доступ до необхідної літератури, яка відсутня у фондах науково-технічної бібліотеки, і до текстів, що не знайдено у інформаційних комп'ютерних мережах. Однак, інформаційно-бібліотечне обслуговування іноземних студентів в даному відділі здійснюється лише через читальний зал; 
- відділ гуманітарної літератури та культурнопросвітницької роботи здійснює обслуговування іноземних студентів в автоматизованому режимі. $Є$ можливість здійснити замовлення необхідної літератури дистанційно (через Інтернет) та отримати відповідну книгу, прийшовши до бібліотеки в зазначений день. Додатково функціонує читальний зал, де іноземні студенти мають можливість отримати необхідну літературу, попередньо зареєструвавшись в електронній базі НТБ;

- читальний зал періодичних видань та літератури 3 українознавства. Обслуговування іноземних студентів в даному відділі відбувається наступним чином: студент попередньо робить запит на веб-сайті НТБ, у покажчиках періодичних та інформаційних видань, а також у каталогах і картотеках щодо інформації про наявність необхідної літератури. Після цього у студента $\epsilon$ можливість відвідати корпус даного відділу бібліотеки та отримати необхідні видання;

- зал електронних каталогів. В даному відділі іноземні студенти мають можливість самостійно скористатись електронним каталогом документів бібліотеки, пошуковою системою, а також отримати доступ до локальних ресурсів НТБ НАУ. В залі постійно знаходиться консультант, що надає допомогу у користуванні пошуковою системою «УФД/Бібліотека»;

- комп'ютерні класи та зал мультимедійних видань. Даний відділ бібліотеки пропонує іноземним студентам різноманітні додаткові послуги, такі як користування Інтернетом, робота за ПК, сканування книжок 3 читального залу та друк, користування мультимедійною електронною бібліотекою, доступ до мереж УРАН, EBSCO, РУБРИКОН і т. ін. За необхідності, кожен студент має можливість отримати консультаційну допомогу.

Варто зазначити, що сучасний розвиток електронних технологій, вносить зміни і в особливості інформаційнобібліотечного обслуговування.

На сьогоднішній день в НТБ НАУ, як і в будь-якій іншій сучасній бібліотеці, найбільшого поширення отримують такі варіанти інформаційного обслуговування іноземних студентів, 
як консультування в режимі онлайн, віртуальний стіл довідок та електронна доставка документів, які вже не є об’єктом авторського права. На думку I. Зарубінської, саме дані напрямки діяльності, надають нові додаткові можливості розвитку інформаційного обслуговування іноземних студентів НТБ НАУ (Зарубінська, 2013).

Отже, іноземні студенти мають однакові можливості доступу до інформації, що і викладачі НАУ та україномовні студенти. Ми можемо також говорити про відповідність інформаційно-ресурсного забезпечення НТБ НАУ інформаційним потребам іноземних студентів. Без сумніву, використання новітніх технологій в роботі НТБ НАУ скорочує шлях інформації до споживача в обличчі іноземного студента, що в багатьох випадках значно полегшує сприйняття інформації студентом та покращує якість інформаційного обслуговування в бібліотеці. Що правда, ми можемо також визначити i шляхи поліпшення інформаційно-ресурсного забезпечення іноземних студентів. Це - оновлення фонду літератури на іноземній мові, створення електронних інформаційних ресурсів на основі традиційного бібліотечного фонду окремо для іноземців, збільшення й урізноманітнення підписки періодичних видань на іноземній мові тощо.

Сьогодні в структурному бібліотечному підрозділі НАУ працює 57 фахівців, більшість з них мають вищу бібліотечну освіту. Колектив бібліотеки має досвід по обслуговуванню іноземних студентів, що накопичувався десятиліттями, багаті бібліотечні фонди, які в цілому можуть задовольнити попит на інформацію різну за тематичною направленістю. Але крім наявності фондів і організації доступу до них, якість бібліотечно-інформаційного обслуговування іноземних студентів залежить від професійної підготовки бібліотекарів, від бажання зрозуміти студента-іноземця і піти йому на зустріч, витративши доволі часу та професійних зусиль. Повсякденна бібліотечна практика потребує від сучасного бібліотекаря зростання професійної кваліфікації на всіх ділянках роботи: при наданні послуг, виконанні довідок, проведенні комплексних заходів, чергуванні у залі каталогів та залах електронної інформації, i особливо у спілкуванні 3 
відвідувачами бібліотеки. Без сумніву, цей аспект слід обов'язково врахувати, розвиваючи інформаційні послуги для іноземних студентів.

Сучасне інтерактивне он-лайн спілкування зі студентами дещо нівелює особливості інформаційного обслуговування іноземців, але «жива» робота, доволі часто приносить певні проблеми. Як з'ясувалось, найбільш проблемним місцем професійної підготовки співробітників НТБ НАУ є слабке знання іноземних мов і недостатнє усвідомлення специфіки даної категорії читачів. В 2016 році силами студентівдокументознавців, що отримують фахову підготовку на кафедрі історії та документознавства ФЛСК НАУ, було розроблено анкету із 12 питань і проведено анкетування співробітників бібліотеки. Анкетування мало на меті виявити проблемні місця в роботі 3 іноземними студентами: 3'ясувати професійну обізнаність бібліотекарів в особливостях роботи з іноземцями; фахову готовність бібліотекарів до такого виду роботи; послуги, якими найчастіше користуються іноземні студенти; володіння іноземними мовами працівників університетської бібліотеки; наявність фонду літератури в НТБ НАУ у відповідності $з$ потребами іноземних студентів тощо. На питання анкети відповіло 80\% співробітників бібліотечного підрозділу. Анкетування показало, що основу колективу бібліотеки складають люди середнього і старшого віку, які не володіють, або слабко володіють іноземними мовами. Крім того, обслуговуючи іноземних студентів, вони частіше за все покладаються на власну інтуїцію та щире бажання допомогти, ніж на професійні знання особливостей цієї категорії споживачів бібліотечної інформації та глибоке розуміння їх інформаційних запитів. Для виправлення ситуації було рекомендовано проводити спеціальні тренінги та семінари силами працівників підготовчого відділення та інших структур, що задіяні у підготовці іноземних студентів, знайомити працівників бібліотеки із національним складом нових наборів студентів. Дуже важливим фактором підвищення якості задоволення інформаційно-освітніх запитів іноземців $\epsilon$ оволодіння бодай елементарними мовними навичками, організація безкоштовних мовних курсів для співробітників 
НТБ НАУ. У порівнянні з 2016 роком деякі зрушення вже відбулись, на роботу прийшло декілька молодих співробітників зі знанням англійської мови, але кардинальна зміна ситуації можлива тільки при систематичній роботі в цьому напрямку всього колективу НТБ і повному усвідомленні важливості вирішення даної проблеми.

Висновки. Отже, Національний авіаційний університет $\epsilon$ одним із провідних закладів вищої освіти, що здійснює підготовку студентів-іноземців, а його бібліотека $є$ тим осередком, який надає інформаційні послуги, забезпечуючи їх освітні потреби. НТБ НАУ здійснює інформаційне забезпечення та обслуговування іноземних студентів на загальних засадах i не має у своєму складі окремого структурного підрозділу для роботи лише 3 даним студентським контингентом, але для іноземних студентів створені достатні умови для інтелектуального та фізичного доступу до інформаційних ресурсів та якісного задоволення їх інформаційно-освітніх запитів.

Встановлено, що для вдосконалення системи інформаційного обслуговування іноземних студентів потрібно здійснити чимало спеціальних заходів, спрямованих на поліпшення існуючої системи обслуговування студентівіноземців. Зокрема, розширити кількість літератури на іноземній мові; створити електронні інформаційні ресурси на основі традиційного бібліотечного фонду окремо для іноземців, збільшити та урізноманітнити підписку періодичних видань на іноземній мові, налагодити контакт із відділами, що найбільше пов'язані із роботою з іноземними студентами тощо. Окремі рекомендації стосуються поліпшення мовної та професійної кваліфікації співробітників бібліотеки. Сподіваємось, що відповідні зміни зможуть поліпшити задоволення інформаційно-освітніх потреб іноземних студентів та в цілому покращать діяльність НТБ НАУ.

\section{ДЖЕРЕЛА ТА ЛІТЕРАТУРА}

1. Бабенко Ж. В. Основні етапи розвитку теорії інформаційних потреб. Бібліотеки в інформаційному cycniльстві: Збірник матеріалів наук.-практ. конференції, 
присвяченої 100-річчю Хмельницької ОУНБ ім. Островського (м. Хмельницький, 21 вересня, 2001 р.). Хмельницький: Б. в. 2001. C. 52-55.

2. Бакало О. М. Особливості навчання іноземних студентів у вищих навчальних закладах (на прикладі Національного авіаційного університету). Проблеми та перспективи розвитку освіти: Матеріали Міжнародної наук.-практ. конференції (м. Київ, 17-18 квітня, 2015 р.). Херсон: Видавничий дім «Гельветика», 2015. С.57-58.

3. Бакало О. М. Врахування національних та індивідуальних особливостей іноземних студентів під час навчання у вищих навчальних закладах України. Сучасний соиіальногуманітарний дискурс: Матеріали V Всеукраїнської наукової конференції з міжнародною участю (м. Дніпропетровськ, 21 березня, 2015р.): у 5-х. частинах. Дніпропетровськ: ТОВ «Інновація», 2015. Ч.1. С. 68-69.

4. Бакало О. М. Педагогічні умови адаптації іноземних студентів до навчання у вищих технічних навчальних закладах: автореф. дис. ... на здобуття наук. ступеня канд. пед. наук: 13.00.04. Київ: Національний авіаційний університет, 2017. $23 \mathrm{c.}$

5. Борик С. М. Бібліотечно-інформаційне обслуговування користувачів: вивчення інформаційних потреб. Сучасні проблеми діяльності бібліотеки в умовах інформаційного cуспільства: Матеріали V Міжнародної наук.- практ. конференції ( м. Львів, 11-12 вересня 2013р.) / Під заг. ред. О. В. Шишка. Львів: Вид-во Львівської політехніки, 2013. C. 499-509.

6. Довгодько Т. І. Загальнонаукова підготовка іноземних студентів до навчання в авіаційному університеті: автореф. дис. ... на здобуття наук. ступеня канд. пед. наук:13.00.04. Київ: Національний авіаційний університет, 2014. 20 с.

7. Зарубінська I. Б. Особливості навчання іноземних студентів при експорті освітніх послуг. Духовність особистості: методологія, теорія $i$ практика. Київ: 2013. Вип.6. С. 103-113. URL: http://nbuv.gov.ua/UJRN/domtp_2 $013 \_6 \_14$. 
8. Коваль Т. Удосконалення системи обслуговування користувачів: сучасні підходи та їх реалізація. Сучасні проблеми діяльності бібліотеки в умовах інформаційного cуспільства: Матеріали IV Міжнар. наук.-практ. конф. ( м. Львів, 25 жовтня 2012 р.). Львів: Вид-во Львів. політехніки. 2012. C. 428-436. URL http://ena.lp.edu.ua:8080/ bitstream/ntb/ 16553/1/43-428-436.pdf

9. Коваль Т. Оптимізація інформаційної діяльності наукової бібліотеки. Наукові праці Національної бібліотеки Украӥни ім. B. I. Вернадського. Київ, 2012. Вип. 34. С. 7-12. URL: http://nbuv.gov.ua/UJRN/npnbuimviv_2012_34_1

10. Коваль Т. Роль наукової бібліотеки в інформаційному забезпеченні вищої освіти. Бібліотечний форум Украӥни. 2007. № 2. С. 20-23.

11. Ковальчук . К. Інформаційно-бібліотечне обслуговування користувачів в сучасних умовах. Бібліотечний вісник. № 11.2013.С. 12-20.

12. Коржик Н. А. Інформаційні потреби користувачів бібліотек вищих навчальних закладів. Вісник ХДАК. Харків, ХДАК, 2007. Вип. 20. С. 108-113.

13. Курченко Т. Є., Паскал Ж. В. Інформаційне обслуговування іноземних студентів в Науково-технічній бібліотеці Національного авіаційного університету. Інформація ma соціум: Збірник матеріалів II Міжнародної наук.-практ. конференції ( м. Вінниця, 28 квітня, 2017 р). Вінниця, ДонНУ імені Василя Стуса, 2017. С.34-37.

14. Мельник Н. І. Стратегічні аспекти розвитку освітнього простору і вимоги маркетингового аналізу до сфери підготовки студентів іноземців. Вісник Книжкової палати. 2003. № 6. С. 35-36.

15. Ніколас Д. Оцінка інформаційних потреб: методи i технології: монографія. Київ: Академія, 2009.76 с.

16. Нілова I. Інформаційні потреби як метазасіб діяльності студентів Наукові пращ⿻і НБУВ. Київ: Нац. б-ка України імені В. I. Вернадського, 2000. Вип. 5. С. 46-54.

17. Павленко Т. Б. Сучасні тенденції розвитку бібліотек вищих навчальних закладів: до 90-річчя Наукової бібліотеки Харківського національного медичного університету. Харків: 
XHMУ, 2012. 11c. URL: http://repo.knmu.edu.ua/ bitstream/ 123456789/134/6/Тенденции Павленко.pdf.

18. Рибаченко Л. І. Підготовка іноземних студентів у навчальних закладах України (1946-2000рр.): автореф. дис.... на здобуття ступеня канд. пед. наук: 13.00.04. Луганськ: Луганський педагогічний університет ім. Т. Г. Шевченка, 2001. $20 \mathrm{c}$.

19. Офіційний веб-сайт Національного авіаційного університету. URL: https://nau.edu.ua/.

20. Офіційний веб-сайт НТБ HAУ. URL: http://www.lib.nau.edu.ua/main/.

21. Офіційний веб-сайт Інституту міжнародного співробітництва і освіти HAУ. URL: http://imco.nau.edu.ua/

22. Офіційний веб-сайт Центру міжнародної освіти НАУ. URL: http://dmz.nau.edu.ua/ua

23. Татьянченко О. О. Педагогічні умови спілкування 3 іноземними студентами в процесі навчання: автореф. дис... на здобуття ступеня канд. пед. наук: 13.00.04. Київ: Київський Національний університет ім. Т. Г. Шевченка, 1997. 24 с.

24. Терещенко H. M. Інформаційне обслуговування іноземних студентів в університетській бібліотеці: автореф. дис..... на здобуття ступеня канд. пед. наук: 13.00.04. Київ: КНУКІМ, 2005. $20 \mathrm{c}$.

25. Тіщенко О. М. Фактори, що впливають на процес адаптації іноземних студентів під час навчання на підготовчому відділенні вищого навчального закладу. Актуальні проблеми вищої професійної освіти: Матеріали Міжнародної наук.практ.конференції, 21-22 березня 2013р. К.: НАУ, 2013. С.99100.

26. Тіщенко О. М. Особливості етапів адаптації іноземних студентів до навчання у вищих навчальних закладах . Сучасні інформачійні технологї та інновачійні методи навчання в підготовиі фахівиів: методологія, теорія, досвід, проблеми. Збірник наук. праць. Київ-Вінниця: ТОВ «Планер», 2014. Вип. 39. C.449-454.

27. Шилюк О. Діяльність вузівської бібліотеки в умовах інформатизації суспільства. Вища школа. 2008. № 5.С. 52-54. 


\section{REFERENCES}

1. Babenko, Zh. V. (2001). Osnovni etapy rozvytku teorii informatsiinykh potreb [Main stages of development of information needs theory]. Biblioteky $v$ informatsiinomu suspilstvi: Proceedings of the scientific-practical conference: dedicated to the 100th anniversary of Khmelnitsky OUNB them. Ostrovsky (pp.52-55). Khmelnitsky, n.p. [in Ukrainian].

2. Bakalo, O. M. (2015). Osoblyvosti navchannia inozemnykh studentiv u vyshchykh navchalnykh zakladakh (na prykladi Natsionalnoho aviatsiiho universytetu) [Peculiarities of teaching foreign students in higher education institutions (on the example of the National Aviation University) ]. Problemy ta perspektyvy rozvytku osvity - Problems and Prospects for the Development of Education: Proceedings of the International Scientific and Practical Conference. (pp.57-58). Kherson: Vydavnychyj dim «Gelvetyka» [in Ukrainian].

3. Bakalo, O. M. (2015). Vrakhuvannia natsionalnykh ta indyvidualnykh osoblyvostei inozemnykh studentiv pid chas navchannia u vyshchykh navchalnykh zakladakh Ukrainy [Consideration of national and individual characteristics of foreign students while studying at higher educational establishments of Ukraine]. Suchasnyi sotsialno-humanitarnyi dyskurs Contemporary Social and Humanitarian Discourse: Proceedings of the 5th All-Ukrainian Scientific Conference with International Participation. Dnipropetrovsk: LLC «Innovaciya», 1(5), 68-69 [in Ukrainian].

4. Bakalo, O. M. (2017). Pedahohichni umovy adaptatsii inozemnykh studentiv do navchannia u vyshchykh tekhnichnykh navchalnykh zakladakh [Pedagogical Conditions for Adaptation of Foreign Students to Study in Higher Technical Institutions]. Extended abstract of Candidate's thesis. Kyiv: Nacionalnyj aviacijnyj universytet [in Ukrainian].

5. Boryk, S. M. (2013). Bibliotechno-informatsiine obsluhovuvannia korystuvachiv: vyvchennia informatsiinykh potreb [Library Information Services: exploring Information Needs]. Suchasni problemy diialnosti biblioteky $v$ umovakh informatsiinoho suspilstva - Modern problems of library activity in the conditions of information society: Proceedings of the $\mathrm{V}$ 
International Scientific and Practical Conference. O. V. Shyshka (ed.). Lviv: Vyd-vo Lviv. Politekhniky, 499-509 [in Ukrainian].

6. Dovhodko, T. I. (2014). Zahalnonaukova pidhotovka inozemnykh studentiv do navchannia $\mathrm{v}$ aviatsiinomu universyteti [General scientific training of foreign students to study at aviation university]. Extended abstract of Candidate's thesis. Kyiv:Nacionalnyj aviacijnyj universytet [in Ukrainian].

7. Zarubinska, I. B. (2013). Osoblyvosti navchannia inozemnykh studentiv pry eksporti osvitnikh posluh [Features of training of foreign students in export of educational services]. Dukhovnist osobystosti: metodolohiia, teoriia $i$ praktyka Personality spirituality: methodology, theory and practice, Kyiv, 6, 103-113. Retrieved from: http://nbuv.gov.ua/ UJRN/ domtp_2013_6_14. [in Ukrainian].

8. Koval, T. (2012). Udoskonalennia systemy obsluhovuvannia korystuvachiv: suchasni pidkhody ta yikh realizatsiia [Improving customer service: current approaches and their implementation]. Suchasni problemy diialnosti biblioteky $v$ umovakh informatsiinoho suspilstva - Modern problems of library activity in the conditions of information society: Proceedings of the IV International Research and Practice Conference. Lviv: Vydavnycztvo Lvivskoyi politexniky, 428-436. Retrieved from: http://ena.lp.edu.ua:8080/ bitstream/ntb/16553/1/43-428-436.pdf [in Ukrainian].

9. Koval, T. (2012). Optymizatsiia informatsiinoi diialnosti naukovoi biblioteky [Optimization of information activity of the scientific library]. Naukovi pratsi Natsionalnoi biblioteky Ukrainy im. V. I. Vernadskoho - Scientific works of the National Library of Ukraine V.I Vernadsky. Kyiv, 34, 7-12. Retrieved from::http://nbuv.gov.ua/UJRN/npnbuimviv_2012_34_1.[in Ukrainian].

10. Koval, T. (2007). Rol naukovoi biblioteky v informatsiinomu zabezpechenni vyshchoi osvity [The Role of the Scientific Library in Higher Education Information Support]. Bibliotechnyi forum Ukrainy Library - Library Forum of Ukraine. 2, 20-23. [in Ukrainian].

11. Kovalchuk , H. K. (2013). Informatsiino-bibliotechne obsluhovuvannia korystuvachiv $\mathrm{v}$ suchasnykh umovakh [Library information services in modern conditions]. Bibliotechnyi visnykLibrary Bulletin, 11, 12-20 [in Ukrainian]. 
12. Korzhyk, N. A. (2007) Informatsiini potreby korystuvachiv bibliotek vyshchykh navchalnykh zakladiv [Information needs of users of libraries of higher education institutions]. Visnyk KhDAKThe CDAC Bulletin. Kharkiv, KhDAK, 20, 108-113 [in Ukrainian].

13. Kurchenko, T. Ye., \& Paskal, Zh.V. (2017). Informatsiine obsluhovuvannia inozemnykh studentiv v Naukovo-tekhnichnii bibliotetsi Natsionalnoho aviatsiinoho universytetu [Information service for foreign students at the National Aviation University Scientific and Technical Library]. Informatsiia ta sotsium Information and Society Information and Society: Proceedings of II International Scientific and Practical Conference. Vinnycya, DonNU imeni Vasylya Stusa, 34-37 [in Ukrainian].

14. Melnyk, N. I. (2003). Stratehichni aspekty rozvytku osvitnoho prostoru i vymohy marketynhovoho analizu do sfery pidhotovky studentiv inozemtsiv [Strategic aspects of the development of educational space and the requirements of marketing analysis in the field of preparation of foreign students]. Visnyk Knyzhkovoi palaty Bulletin of the Book Chamber, 6, 35-36 [in Ukrainian].

15. Nikolas, D. (2009). Otsinka informatsiinykh potreb: metody $i$ tekhnolohii [Information needs assessment: methods and technologies]. Kyiv: Akademiya [in Ukrainian].

16. Nilova, I. (2000). Informatsiini potreby yak metazasib diialnosti studentiv [Information Needs as a Metadata for Students Activities]. NBUW Research -2000 - Scientific works of NBU2000. Kyiv: Nacz. b-ka Ukrayiny`imeni V. I. Vernads`kogo, 5, 46-54 [in Ukrainian].

17. Pavlenko, T. B. (2012). Suchasni tendentsii rozvytku bibliotek vyshchykh navchalnykh zakladiv: do 90-richchia Naukovoi biblioteky Kharkivskoho natsionalnoho medychnoho universytetu [Modern tendencies of development of libraries of higher educational institutions: dedicated to the 90th anniversary of the Scientific Library of Kharkiv National Medical University]. Kharkiv: KhNMU. Retrieved from:http:// repo.knmu.edu.ua/ bitstream/ 123456789/ 134/6/ Tendentsyy_Pavlenko.d. [in Ukrainian].

18. Rybachenko, L. I. (2001). Pidhotovka inozemnykh studentiv u navchalnykh zakladakh Ukrainy (1946-2000 rr.) [Preparation of foreign students in educational institutions of Ukraine (1946-2000)]. 
Extended abstract of Candidate's thesis. Lugansk: Luganskyj pedagogichnyj universytet im. T. G. Shevchenka [in Ukrainian].

19. Ofitsiynyi vebsait Natsionalnoho aviatsiynoho universytetu [The official website of National Aviation University]. nau.edu.ua. Retrieved from https://nau.edu.ua/ [in Ukrainian].

20. Ofitsiynyi vebsait NTB NAU [The official website of the Scientific and Technical Library of NAU]. www.lib.nau.edu.ua/main. Retrieved from http://www.lib.nau.edu.ua/main/ [in Ukrainian].

21. Ofitsiinyi vebsait Instytutu mizhnarodnoho spivrobitnytstva i osvity [Official site of the Institute of International Cooperation and Education of NAU]. www.imco.nau.edu.ua/. Retrieved from: http://imco.nau.edu.ua/ [in Ukrainian].

22. Ofitsiinyi vebsait Tsentru mizhnarodnoi osvity NAU [Official site of the NAU Center for International Education]. www.dmz.nau.edu.ua/ua. Retrieved from: http://dmz.nau.edu.ua/ua. [in Ukrainian].

23. Tatianchenko, O. O. (1997). Pedahohichni umovy spilkuvannia $\mathrm{z}$ inozemnymy studentamy $\mathrm{v}$ protsesi navchannia [Pedagogical conditions of communication with foreign students in the course of study]. Extended abstract of Candidate's thesis. Kyiv: Nacionalnyj universytet imeni T. G. Shevchenka [in Ukrainian].

24. Tereshchenko, N. M. (2005). Informatsiine obsluhovuvannia inozemnykh studentiv $\mathrm{v}$ universytetskii bibliotetsi [Information service for foreign students in the university library]. Extended abstract of Candidate's thesis. Kyiv: KNUKIM [in Ukrainian].

25. Tishchenko, O. M. (2013). Faktory, shcho vplyvaiut na protses adaptatsii inozemnykh studentiv pid chas navchannia na pidhotovchomu viddilenni vyshchoho navchalnoho zakladu [Factors influencing the adaptation process of foreign students while studying at the preparatory department of a higher education institution]. Aktualni problemy vyshchoi profesiinoi osvity - Topical problems of higher vocational education: Proceedings of the International Science and Practice Conference. Kyiv: Nacionalnyj aviacijnyj universytet, 99-100 [in Ukrainian].

26. Tishchenko, O. M. (2014). Osoblyvosti etapiv adaptatsii inozemnykh studentiv do navchannia u vyshchykh navchalnykh zakladakh [Features of stages of adaptation of foreign students to 
study at higher education institutions]. Suchasni informatsiini tekhnolohii ta innovatsiini metody navchannia $v$ pidhotovtsi fakhivtsiv: metodolohiia, teoriia, dosvid, problemy - Modern information technologies and innovative methods of training in the training of specialists: methodology, theory, experience, problems. Kyiv-Vinnycya: TOV «Planer», 39, 449-454 [in Ukrainian].

27. Shyliuk, O. (2008). Diialnist vuzivskoi biblioteky v umovakh informatyzatsii suspilstva [Activities of the university library in the conditions of informatization of the society]. Vyshcha shkola-High scool, 5, 52-54 [in Ukrainian].

\section{АНОТАЦІЯ}

У статті узагальнено практичний досвід забезпечення інформаційно-освітніх потреб студентів-іноземців в Науковотехнічній бібліотеці Національного авіаційного університету. Проведено аналіз теоретичних засад та сучасного практичного досвіду організації роботи з іноземними студентами в закладах вищої освіти України, виявлено особливості иієї категорії студентів, щуодо забезпечення інформаційних потреб в прочесі навчання, спрощення їх адаптації до умов освітнього, інформаційного та побутового середовища країни перебування.

У статті зазначається, щзо Національний авіаційний університет є одним із провідних навчальних закладів, щуо надає освітні послуги іноземним студентам. 3'ясовано, щуо Науково-технічна бібліотека НАУ здійснює інформаційне забезпечення та обслуговування іноземних студентів на загальних засадах $i$ не має у своєму складі окремого структурного підрозділу для роботи лише з циим студентським контингентом. Але для іноземних студентів створені достатні умови для інтелектуального та фізичного доступу до інформаційних ресурсів через сайт бібліотеки $і$ в ї комп'ютерних класах.

У статті також розглядаються проблеми, пов'язані з безпосереднім обслуговуванням іноземних студентів у підрозділах бібліотеки $i$ професійною готовністю бібліотечного персоналу до спілкування, щзо має певну специфіку. 
3'ясовано щзо Науково-технічна бібліотека НАУ за десятиліття роботи з іноземними студентами набула иікавого $і$ корисного досвіду з організації роботи з изією категорією читачів та забезпеченню їх інформаційно-освітніх потреб. Обгрунтовано необхідність узагальнення та поширення иього досвіду, як і удосконалення забезпечення інформаційних потреб іноземних студентів в НТБ НАУ.

Ключові слова: інформація, інформачійні послуги, інформаційно-освітні потреби, студенти-іноземиі, бібліотека, Науково-технічна бібліотека Національного авіаційного університету.

\section{АННОТАЦИЯ}

В статье обобщен практический опыт обеспечения информационно-образовательных нужд студентовиностранцев в Научно-технической библиотеке Нациионального авиационного университета. Проведен анализ теоретических основ и современного практического опыта организации работы с иностранными студентами в высших учебных заведениях Украины, выявлено особенности этой категории студентов по отночению $\kappa$ обеспечению информационных запросов в прочессе обучения, улучшению их адаптации к условиям образовательной, информационной $и$ бытовой среды страны пребывания.

В статье отмечается, что Начиональный авиационный университет является одним из ведущих высших учебных заведений, которые осуществляют подготовку студентовиностранцев. Установлено, что Научно-техническая библиотека НАУ осуществляет информационное обеспечение и обслуживание иностранных студентов на общих основаниях $u$ не имеет в своем составе отдельного структурного подразделения для работь исключительно с этим контингентом студентов. Но для иностранных студентов созданы достаточные условия для интеллектуального и физического доступа $к$ информационньм ресурсам посредством сайта библиотеки и в ее компьютерных классах.

B cтатье также рассматриваются проблемы, связанные с непосредственным обслуживанием иностранных 
студентов в подразделениях библиотеки и профессиональной готовностью персонала библиотек к общению с ними, что имеют определенную специифику.

Установлено, что Научно-техническая библиотека НАУ за десятилетия работы с иностранными студентами приобрела ценный и полезный опыт по организации работы с этой категорией читателей и удовлетворению их информационно-образовательных нужд. Обосновано необходимость обобщения и распространения этого опыта, как и усовершенствования удовлетворения информаџионных запросов иностранных студентов в НТБ НАУ.

Ключевые слова: информация, информационные услуги, информационно-образовательные нужды, студентыиностранцы, библиотека, Научно-техническая библиотека Национального авиаџионного университета. 